\title{
Peningkatan Produksi dan Kualitas Benih Okra (Abelmoschus esculantus L. Moench) Menggunakan Aplikasi Fosfor dan GA3
}

\author{
Enhancement Production and Quality of Okra (Abelmoschus esculantus L. Moench) \\ seeds by application of Phosphorus and $\mathrm{GA}_{3}$
}

\author{
Author(s): Nisa Budi Arifiana ${ }^{(1) *}$; Sigit Soeparjono ${ }^{(1)}$; Sholeh Avivi ${ }^{(1)}$ \\ (1) Fakultas Pertanian, Universitas Jember \\ * Corresponding author: nisabudiarifiana@gmail.com
}

\section{Submitted: 09 Jul $2020 \quad$ Accepted: 29 Aug $2020 \quad$ Published: 30 Sep 2020}

\begin{abstract}
ABSTRAK
Tanaman Okra menjadi salah satu komoditas yang masih belum besar di Indonesia, namun memiliki jumlah permintaan yang terus bertambah. Produksi Okra dalam negeri masih fluktuatif sehingga belum memenuhi kebutuhan nasional. Kurangnya produksi polong okra salah satunya disebabkan oleh ketersediaan benih yang masih terbatas. Upaya meningkatkan produksi dan kualitas benih okra melalui aplikasi pupuk fosfor dan $\mathrm{GA}_{3}$. Pupuk fosfor dapat membantu dalam proses metabolisme pertumbuhan tanaman dan sebagai sumber energi untuk pembelahan dan pembesaran sel dalam pembentukan bunga, buah dan biji. Aplikasi $\mathrm{GA}_{3}$ juga mampu meningkatkan sistem metabolisme dan menghasilkan akumulasi fotosistat sehinggamenghasilkan presentase daya tumbuh benih lebih baik. Penelitian disusun berdasarkan rancangan acak kelompok dua faktor yaitu faktor pertama dosis pupuk Fosfor yaitu, P1 (75kg/ha SP-36), P2 (100kg/ha SP-36), P3 (125kg/ha SP-36) dan P4 (150kg/ha SP-36). Faktor kedua konsentrasi GA 3 yaitu, G0 (tanpa aplikasi GA 3$)$, G1 (50 mg/l), G2 (100mg/l), dan G3 (150mg/l). Sehingga terdapat 16 kombinasi perlakuan dengan ulangan 3 kali. Data dianalisis menggunakan uji lanjut jarak berganda duncan $(\alpha, 5 \%)$ dan uji beda nyata terkecil $(\alpha, 5 \%)$. Hasil penelitian aplikasi GA $30 \mathrm{mg} / \mathrm{l}$ dapat meningkatkan berat biji per polong 3,77 gram, berat biji per tanaman 49,2 gram dan produksi benih 1,98 ton/ha. Kualitas benih pada presentase benih bernas dapat meningkat hingga $96 \%$ pada aplikasi konsentrasi GA $100 \mathrm{mg} / \mathrm{l}$. Pemberian fosfor $75 \mathrm{~kg} / \mathrm{ha}$ SP-36 dan konsentrasi GA $30 \mathrm{mg} / \mathrm{l}$ memberikan interaksi pada daya berkecambah benih $90 \%$ dan karbohidrat benih $42 \%$.
\end{abstract}

Kata Kunci:

Okra;

Produksi Benih;

Kualitas Benih;

\section{Keywords:}

Okra;

Seed

Production;

Seed Quality;

\section{ABSTRACT}

Okra is one of the vegetable commodities that remains unpopular in Indonesia, but in another case, it has demand opportunity to continues and increases. Production of okra is still fluctuated and does not fulfill the national request of okra pods. The less of okra pods because of limited okra seeds. An effort to increase the production and quality of okra seed can be done through the application of phosphorus fertilizer and $\mathrm{GA}_{3}$. Phosphorus fertilizer supports the metabolic process of plant growth and as a source of energy for cell division and cell division in flower, fruit, and seeds formation. $\mathrm{GA}_{3}$ application able to increase the metabolic system and produced photosynthate accumulation therefore increase the percentage of seed growing. The experimental used was Randomized Block Design (RBD) with 2 factors, the first factor was the dose of phosphorus fertilize consisted of 4 levels: P1 (75kg/ha SP-36), P2 (100kg/ha SP-36), P3 (125kg/ha SP-36) and P4 (150kg/ha SP-36). The second factor was concentration of $\mathrm{GA}_{3}$ consists of 4 levels: $\mathrm{G} 0$ (without application $\mathrm{GA}_{3}$ ), G1 $(50 \mathrm{mg} / \mathrm{l}), \mathrm{G} 2(100 \mathrm{mg} / \mathrm{l})$, dan G3 $(150 \mathrm{mg} / \mathrm{l})$. The analysis used Duncan's multiple continue test $(\alpha, 5 \%)$ and Least Significant Different (LSD)( $(\alpha, 5 \%)$. The result application $\mathrm{GA}_{3} 50 \mathrm{mg} / \mathrm{l}$ can increase seed weight per pod, seed weight per plant, and seed production per hectare. Application $100 \mathrm{mg} / \mathrm{l}$ of $\mathrm{GA}_{3}$ increases seed quality in the percentage of $96 \%$ pithy seeds. Combination of Phosphorus fertilization $75 \mathrm{~kg} / \mathrm{ha} \mathrm{SP-36}$ and $\mathrm{GA} A_{3}$ concentration of $50 \mathrm{mg} / \mathrm{l}$ results in increasing in seed germination and seed carbohydrate content. 


\section{PENDAHULUAN}

Di Indonesia tanaman okra mulai banyak dibudidayakan untuk dimanfaatkan sebagai sayuran dan bahan obat-obatan. Walaupun permintaan terhadap sayuran okra masih relatif sedikit, namun kebutuhan domestik meningkat setiap tahunnya dan produksi okra dalam negeri belum memenuhi kebutuhan masyarakat. Menururt Ichsan et al., (2016) produksi okra saat ini masih cenderung fluktuatif dan belum mampu memenuhi kebutuhan sayuran okra nasional. Produksi okra pada tahun 2013 sebesar 1.317 ton dan pada tahun 2014 sebesar 1.360 ton, sedangkan kebutuhan okra pada tahun 2015 diproyeksikan mencapai 1.500 ton. Berdasarkan produsen sayuran okra di PT. Mitra Tani Dua Tujuh permintaan okra skala ekspor relatif tinggi belum memenuhi target permintaan pasar (Indreswari, 2015).

Budidaya okra di Indonesia masih belum diimbangi dengan ketersediaan benih okra, sering kali ditemukan ketersediaan benih okra di pasaran terbatas sehingga kebutuhan produksi belum tercapai (Barutu, 2016). Berdasarkan data Kirana et al. (2015), produksi biji okra mampu menghasilkan 1,67 ton/ha. Sebelumnya Abd El-Kader et al., (2010) menyatakan bahwa produksi okra di beberapa negara tropis belum optimum dan kualitas polong yang rendah akibat terus menurunnya kesuburan tanah.

Upaya untuk memenuhi kebutuhan benih dan ketersediaan okra salah satunya melalui perbaikan teknik budidaya tanaman okra. Pemberian pupuk berimbang akan mampu meningkatkan pertumbuhan tanaman, meningkatkan produksi tanaman dan kualitas panennya. Berdasarkan Standart Operasional Prosedur budidaya tanaman okra (Kirana et al., 2015) didalam SOP budidaya sayuran okra dan produksi benih memiliki prosedur yang relatif sama dalam teknik budidayanya, hal ini yang membedakan dalam penanganan panen dan pasca panen sayuran okra dan benih okra. Upaya untuk meningkatkan produksi dan kualitas benih okra memerlukan inovasi budidaya seperti pemberian pupuk fosfor dan hormon giberelin .

Upaya meningkatkan produktivitas tanaman tidak hanya melalui nutrisi, namun juga melalui pemberian hormon eksogen seperti $\mathrm{GA}_{3}$. Pemupukan fosfor dan pemberian giberelin mampu membantu proses pembelahan dan pembesaran sel. Fosfor menjadi bagian esesensial dalam gula fosfat dalam proses respirasi dan metabolisme lain. Menurut Hadisuwito, (2012) fosfor dapat membantu tanaman dalam pertumbuhan tanaman, pertumbuhan bunga, biji dan pemasakan buah. Khandaker et al., (2018) pemberian $\mathrm{GA}_{3}\left(\mathrm{GA}_{3}\right)$ dengan konsentrasi 120 ppm memberikan hasil terbaik pada pertumbuhan, pengembangan dan kualitas okra dengan peningkatan jumlah bunga okra, meningkatkan kualitas polong, dan meningkatkan presentase kesehatan benih okra. Berdasarkan uraian tersebut, penelitian ini bertujuan untuk menentukan kombinasi perlakuan dan perlakuan tunggal aplikasi dosis pupuk fosfor dan konsentrasi $\mathrm{GA}_{3}$ terhadap peningkatan produksi dan kualitas benih okra.

\section{METODOLOGI}

Penelitian ini dilaksanakan pada November hingga April 2020 bertempat di Lahan Percobaan Antirogo, Laboratorium Biosain dan Laboratorium Teknologi Benih Politeknik Negeri Jember.

Penelitian disusun berdasarkan rancangan acak kelompok yang terdiri dari dua faktor, yaitu faktor pertama dosis pupuk P yaitu, P1 (75kg/ha SP-36), P2 (100kg/ha SP-36), P3 (125kg/ha SP-36) dan P4 (150kg/ha SP-36). Faktor kedua adalah konsentrasi hormon $\mathrm{GA}_{3}$ yaitu: $\mathrm{G} 0$ (tanpa aplikasi $\left.\mathrm{GA}_{3}\right), \mathrm{G} 1$ (50 mg/l), G2 (100mg/l), dan G3 (150mg/l). Sehingga terdapat 16 kombinasi perlakuan dengan ulangan 3 kali. 
Aplikasi pupuk Fosfor dilakukan seminggu sebelum tanaman bersamaan saat pemupukan dasar. Aplikasi $\mathrm{GA}_{3}$ dengan cara penyemprotan dilakukan pada 3 fase, yaitu fase vegetatif menjelang berbunga, fase generatif pada saat anthesis (bunga mekar), dan fase pengisian biji (buah muda). Penyemprotan $\mathrm{GA}_{3}$ dilakukan pada seluruh tanaman secara merata sesuai dengan taraf konsentrasi perlakuan. Pemanenan benih okra dapat dilakukan mulai tanaman berumur $\pm 90 \mathrm{hst}$ secara berkala dengan ditandai polong kering, adanya perubahan warna menjadi kecoklatan dan retak pada bagian polong okra. Polong yang telah dipanen kemudian dikeringkan di bawah sinar matahari selama kurang lebih 3 hari atau tergantung dari intensitas matahari. Setelah polong kering, benih okra diekstraksi atau dilakukan pembersihan benih dari bagian polong atau kulit polong. Pengujian produksi dan kualitas benih okra dilakukan dengan variabel pengamatan sebagai berikut:

1. Berat benih per polong, ditentukan dengan menghitung berat benih yanng terbentuk pada tiap polong okra dari tanaman sampel.

2. Berat biji per tanaman, menghitung berat biji pertanaman dengan mehintung berat biji keseluruhan dari tanaman sampel.

3. Produksi Polong, diperoleh dari akumulasi berat polong tanaman sampel yang telah dikonfersikan dalam satuan luas.

4. Presentase benih bernas

Pengamatan benih bernas okra ditandai dengan permukaan benih halus, tidak mengkerut/gepeng, benih padat dan berwarna coklat kehitaman. Presentase benih bernas diamati dengan menghitung benih bernas dari keseluruhan benih yang dihasilkan pada setiap polong yang dikonfersikan dalam bentuk persentase.

5. Daya berkecamabah benih

Pengamatan daya berkecambah benih untuk mengetahui pengaruh pemberian fosfor dan $\mathrm{GA}_{3}$ terhadap kualitas fisiologis benih. Daya berkecambah dihitung berdasarkan persentase jumlah kecambah normal $(\mathrm{KN})$ dari jumlah benih yang dikecambahkan.

6. Karbohidrat benih

Pengukuran kandungan karbohidrat ditentukan menggunakan metode yang dikembangkan Sadasivam and Manickam (2007). Sebanyak 3 gram biji okra dihidrolisis dengan $5 \mathrm{ml}$ larutan 2,5 $\mathrm{N} \mathrm{HCl}$ dan dipanaskan dalam waterbath selama 3 jam dan setelah dingin dinetralisir dengan $\mathrm{Na}_{2} \mathrm{CO}_{3}$. Larutan sampel dimasukkan ke dalam labu ukur $100 \mathrm{ml}$ dan digenapkan dengan akuades hingga garis tera lalu digojok selama 30 menit menggunakan sentrifus dengan kecepatan $3.000 \mathrm{rpm}$. Sebanyak 0,5 ml supernatan ditambahkan dengan $2 \mathrm{ml}$ reagen Anthronem dan dipanaskan dalam waterbath selama 8 menit pada suhu $40^{\circ} \mathrm{C}$. Setelah supernatan dingin kemudian dilakukan pengukuran absorbansi menggunakan spektrofotometer pada panjang gelombang $630 \mathrm{~nm}$.

\section{HASIL DAN PEMBAHASAN}

Hasil analisis sidik ragam pada perlakuan aplikasi fosfor dan $\mathrm{GA}_{3}$ menunjukkan bahwa masing-masing perlakuan memberikan pengaruh yang nyata dan menunjukkan adanya interaksi dari kedua perlakuan. Rekapitulasi sidik ragam pada variabel pengamatan dapat dilihat pada Tabel 1. 
Tabel 1. Rekapitulasi Sidik Ragam pada Variabel Pengamatan

Table 1. Reapitulation of Variance on Variable Observation

\begin{tabular}{|c|c|c|c|c|c|}
\hline \multirow{2}{*}{$\begin{array}{l}\text { Parameter } \\
\text { Parameter }\end{array}$} & \multicolumn{4}{|c|}{$\begin{array}{l}\text { Kuadrat Tengah } \\
\text { Middle Quadrant }\end{array}$} & \multirow{2}{*}{$\begin{array}{l}\text { Coefficien } \\
\text { of } \\
\text { Diversity }\end{array}$} \\
\hline & $\begin{array}{l}\text { Fosfor } \\
\text { Phosphorus }\end{array}$ & $\begin{array}{l}\mathrm{GA}_{3} \\
G A_{3}\end{array}$ & $\begin{array}{l}\text { Interaksi } \\
\text { Interaction }\end{array}$ & $\begin{array}{l}\text { Galat } \\
\text { Error }\end{array}$ & \\
\hline \multicolumn{6}{|c|}{$\begin{array}{c}\text { Produksi Biji } \\
\text { Seed Production }\end{array}$} \\
\hline $\begin{array}{l}\text { Berat Biji Per Polong } \\
\text { Seed Weight per Pot }\end{array}$ & $0,09 \mathrm{~ns}$ & $0,39 * *$ & $0,10 \mathrm{~ns}$ & 0,077 & $7,85 \%$ \\
\hline $\begin{array}{l}\text { Berat Biji Per Tanaman } \\
\text { Seed Weight per Plants }\end{array}$ & $123,03 \mathrm{~ns}$ & $365,69 * *$ & $118,5 \mathrm{~ns}$ & 62,58 & $19,75 \%$ \\
\hline $\begin{array}{l}\text { Produksi Biji per Ha } \\
\text { Seed Production per Ha }\end{array}$ & $0,21 \mathrm{~ns}$ & $0,63 * *$ & $0,21 \mathrm{~ns}$ & 0,12 & $19,75 \%$ \\
\hline \multicolumn{6}{|c|}{$\begin{array}{l}\text { Kualitas Biji } \\
\text { Seed Quality }\end{array}$} \\
\hline $\begin{array}{l}\text { Presentase Biji Bernas } \\
\text { Percentage of Seeds } \\
\text { Fertilized }\end{array}$ & $0,0002 \mathrm{~ns}$ & $0,0037 * *$ & $0,0005 \mathrm{~ns}$ & 0,0006 & $2,69 \%$ \\
\hline $\begin{array}{l}\text { Karbohidrat } \\
\text { Carbohydrate }\end{array}$ & $1,93 * *$ & $0,02 * *$ & $0,01 * *$ & 0,0014 & $0,09 \%$ \\
\hline $\begin{array}{l}\text { Daya Berkecambah Biji } \\
\text { Seed Germination }\end{array}$ & $38,13 * *$ & $681,63 * *$ & $375,15 * *$ & 0,110 & $0,44 \%$ \\
\hline
\end{tabular}

Keterangan : $\quad \mathrm{ns}=$ berbeda tidak nyata; $*$ = berbeda nyata; $* *=$ berbeda sangat nyata

Information : $\quad n s=$ not significant $; *$ significant; $* *=$ the most significant

1. Produksi Biji

Hasil penelitian menunjukkan bahwa aplikasi $\mathrm{GA}_{3}$ berpengaruh terhadap berat biji per polong dan berat biji per tanaman. Pada hasil uji lanjut menunjukkan aplikasi
$\mathrm{GA}_{3}$ dengan konsentrasi $50 \mathrm{mg} / \mathrm{l}$ menghasilkan rata-rata terbaik pada berat biji per polong dan berat biji per tanaman. Berdasarkan hasil uji lanjut dapat dilihat pada Tabel 2 .

Tabel 2. Aplikasi $\mathrm{GA}_{3}$ terhadap Variabel Produksi Biji

Table 2. GA3 Aplication in Varible Seed Productiom

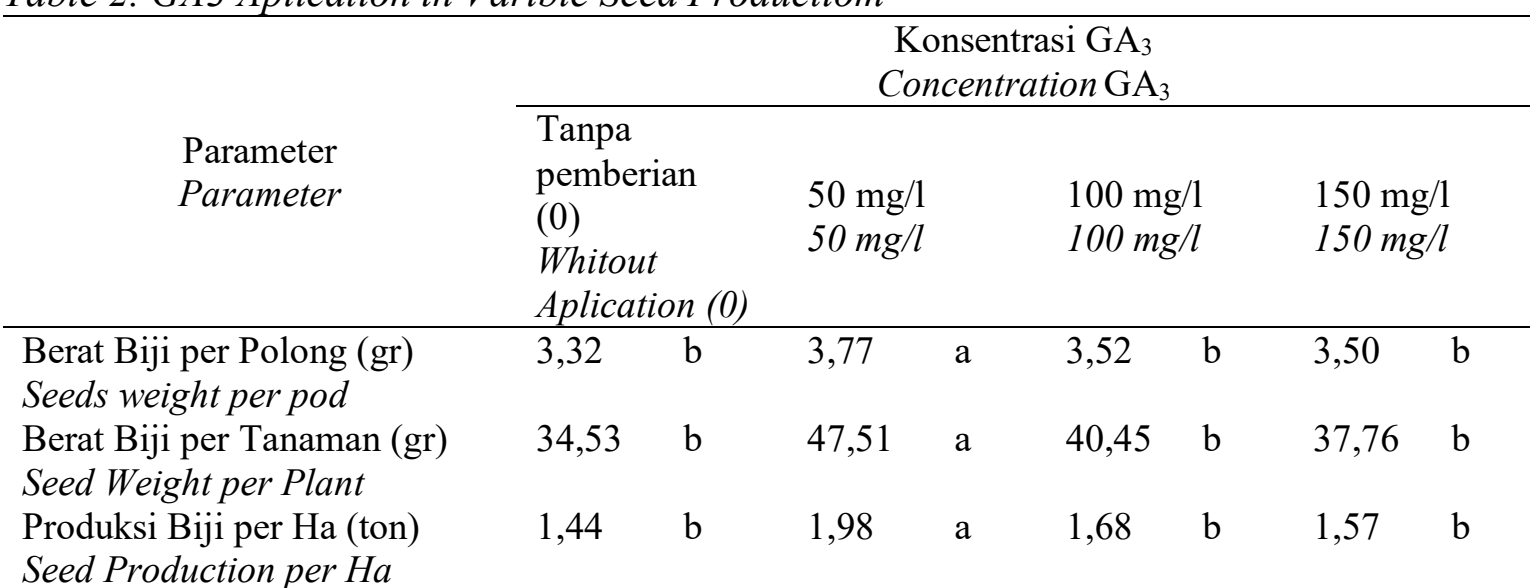

Keterangan: Angka pada kolom yang sama yang diikuti oleh huruf yang sama pada masing-masing variebel berbeda tidak nyata berdasarkan uji BNT taraf $5 \%$.

Information: Nominal in the same column that followed by the same alphabet in each variable was not significant based on the LSD test at a 5\% level. 
Berdasarkan hasil pada Tabel 2 menjelaskan bahwa tanaman yang diberikan konsentrasi $\mathrm{GA}_{3} \quad 50 \mathrm{mg} / 1$ menghasilkan berat biji per polong 3,77 gram, berat biji per tanaman 47,51 gram dan produksi biji 1,98 ton/ha. Berdasarkan data Kirana et al., (2015) pemberian GA3 pada tanaman okra dapat meningkatkan produksi biji okra sebesar berat 30 gram per tanaman dan menghasilkan 1,67 ton/ha benih okra. Hal ini terjadi karena dengan pemberian GA3 pada tanaman dapat berpengaruh terhadap peningkatan translokasi hasil fotosintat dan energinya untuk pembesaran dan pebelahan sel.

Selama masa pembentukan dan pengisian biji dapat terjadi penambahan ukuran dan berat biji. Pada tahap perkembangan tersebut, biji masih berukuran sangat kecil, namun seiring dengan pertumbuhan biji, biosintesis giberelin dalam biji semakin besar. Ukuran biji secara perlahan akan bertambah yang disebabkan oleh penambahan volume pada endosperm yang berkaitan dengan peningkatan ukuran kantung embrio. Menurut Wiraatmaja (2017), giberelin dapat difungsikan dalam membantu proses metabolik yang menyebabkan pertumbuhan embrio. Penelitian sebelumnya oleh Wijayanto et al. (2012) aplikasi giberelin pada semangka dapat meningkatkan proses pematangan dan pertumbuhan endosperm dan embrio. Kandungan giberelin didalam biji akan menurun selama proses pematangan biji.

Aplikasi hormon giberelin pada tanaman okra dapat membantu perkembangan dalam pembentukan biji melalui pemkembangan endosperm dan embrio yang mengalami penambahan volume secara maksimal sehingga pengisian biji lebih optimal. Pengisian biji yang optimal akan mengakibatkan pertambahan berat setiap biji, sehingga berpengaruh terhadap berat biji per polong yang diakumulasi menjadi berat biji per tanaman, berat biji per petak dan dengan demkian produksi biji per ha dapat meningkat. Respon tanaman okra terhadap aplikasi $\mathrm{GA}_{3}$ menunjukkan adanya peningkatan produksi biji pada tanaman yang diberi perlakuan $\mathrm{GA}_{3}$ $50 \mathrm{mg} / 1$. Menurut Shahid et al. (2013), pemberian zat pengatur tumbuh salah satunya asam giberelat memberikan pengaruh terhadap peningkatan hasil benih per luasan dan kualitas benih okra. Berdasarkan hasil penelitian Muharram et al. (2015), pemberian giberelin pada biji duwet dapat meningkatkan ukuran diameter biji.

Pemberian pupuk fosfor dengan berbagai dosis menunjukkan berpengaruh tidak nyata terhadap berat bji per polong, berat biji per tanaman, dan produksi per Ha. Kegunaan fosfor pada tanaman dapat mempercepat perbungaan, pemasakan buah dan biji, namun berdasarkan hasil penelitian yang telah dilaksanakan, pemberian pupuk SP-36 menunjukkan pengaruh yang tidak nyata terhadap variabel pengamatan produksi biji. Hal ini terkait aplikasi pupuk fosfor yang diberikan hanya sekali pada saat pemupukan dasar dan musim hujan sehingga dapat berdampak pupuk fosfor tercuci akibat terbawa aliran air hujan. Menurut Winata et al., (2014) pupuk SP-36 memiliki sifat mudah larut dalam air sehingga sangat rawan tercuci apabila terjadi hujan. Berdasarkan hasil penelitiannya penambahan arang pada SP36 mampu menjerap usur hara untuk tidak mengalami pencucian akibat dari aliran air hujan bila dibandingkan dengan pemberian SP-36. Sehingga penggunaan arang diduga mampu mengurangi hanyutnya $P$ yang tersedia akibat guyuran hujan. Dengan ini kebutuhan unsur $P$ dalam meningkatkan produksi biji tidak terpenuhi secara maksimal.

2. Kualitas Biji

Berdasarkan hasil penelitian, aplikasi

$\mathrm{GA}_{3}$ berpengaruh nyata terhadap 
presentase biji bernas. Hasil uji lanjut menunjukkan bahwa aplikasi $\mathrm{GA}_{3}$ dengan konsentrasi $50 \mathrm{mg} / \mathrm{l}$ menghasilkan rata-rata persentase biji bernas tertinggi. Berdasarkan hasil uji lanjut dapat dilihat pada Tabel 3.

Tabel 3. Aplikasi GA 3 terhadap Presentase Biji Bernas

Table 3. GA3 Aplication to precentage of Seeds Fertilized

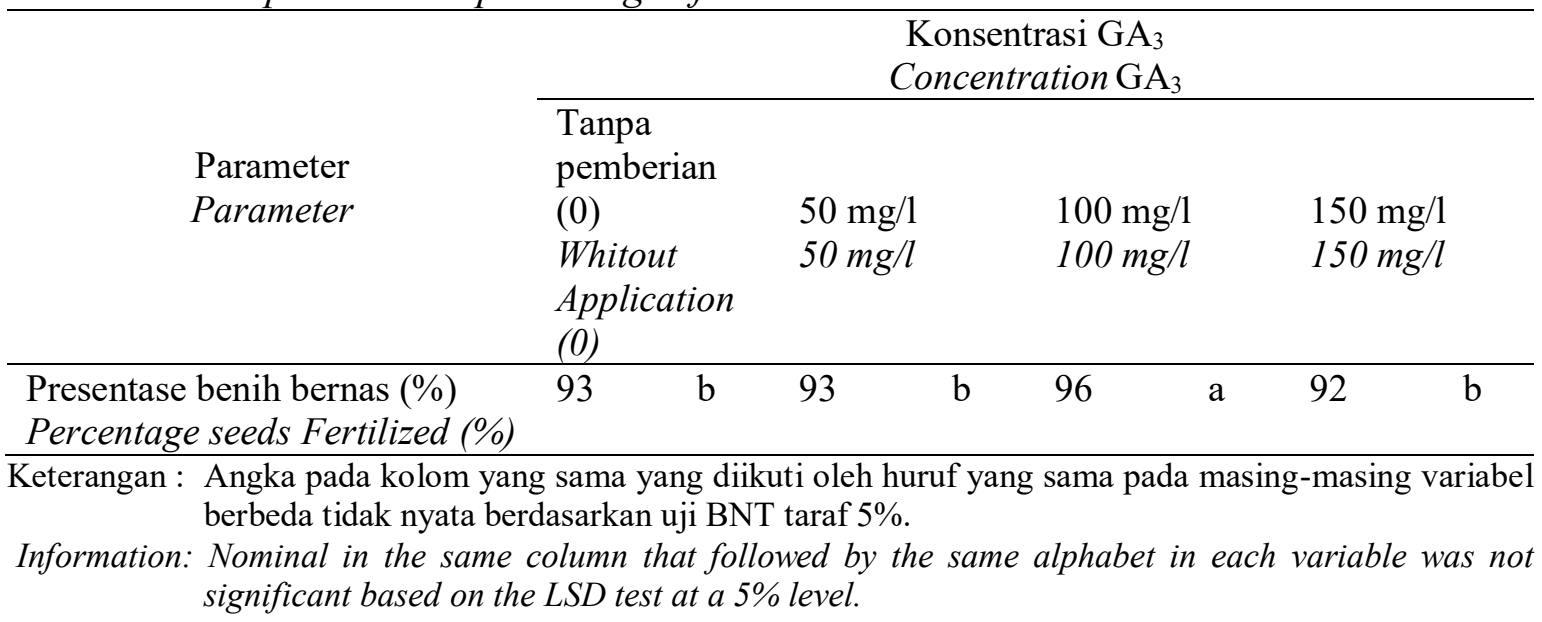

Berdasarkan hasil uji lanjut BNT pada Tabel 3, aplikasi GA 3 sebanyak 100 $\mathrm{mg} / \mathrm{l}$ pada tanaman okra dapat meningkatkan persentase benih bernas sebesar 96\%. Presentase benih bernas merupakan perolehan dari perbandingan jumlah benih bernas terhadap total jumlah benih. Benih dikatakan bernas apabila pengisian cadangan makanan pada biji telah terisi maksimum dalam memenuhi kebutuhan proses metabolisme saat perkecambahan benih. Berdasarkan dengan aplikasi $\mathrm{GA}_{3}$ yang terbukti nyata meningkatkan persentase benih bernas, aplikasi fosfor pada tanaman okra memberikan pengaruh tidak nyata terhadap presentase benih bernas. Hal ini diduga aplikasi fosfor diberikan hanya sekali pada saat pemupukan dasar telah dimobilisasi untuk pertumbuhan tanaman terbukti dengan adanya pengaruh terhadap jumlah ruas dan luas daun tanaman okra pada masa pertumbuhan tanaman. Dengan demikian unsur fosfor yang terserap cukup untuk memenuhi kebutuhan pertumbuhan tanaman saja.

Aplikasi $\mathrm{GA}_{3}$ dapat membantu pembentukan buah dan biji. Hal ini sesuai dengan penelitian Muhyidin et al. (2018) yang melaporkan bahwa aplikasi $\mathrm{GA}_{3}$ pada tanaman tomat mampu meningkatkan jumlah buah. Penelitian sebelumnya oleh Arifin et al (2012) menghasilkan penelingkatan jumlah biji cabe merah keriting yang diberi $\mathrm{GA}_{3}$ dengan konsentrasi 20 ppm. $\mathrm{GA}_{3}$ membantu dalam perkembangan embrio dan penambahan volume endosperm pada masa pembentukan dan pengisian biji. Proses ini akan berjalan sampai perkembangan embrio dan volume endosperm mencapai maksimum. Biji yang bernas diindikasikan dengan ukuran biji yang besar dan didukung oleh cadangan makanan berupa endosperm yang telah terbentuk maksimum. Menurut (Zulkarnain, 2010) hormon auksin dan giberelin mambantu dalam pembelahan sel dan meningkatkan kadar hormon saat pertumbuhan biji dalam buah. Pemberian giberelin secara eksogen bermanfaat dalam membantu proses pematangan dan pertumbuhan endosperm dan embrio. Perkembangan buah akan tetap terjadi dengan penambahan giberelin eksogen, namun pemberian hormon tersebut pada konsentrasi tertentu dapat mengakibatkan

terhambatnya 
pertumbuhan embrio sehingga biji tidak terbentuk.

Pengaruh pemberian giberelin dapat membantu dalam memaksimalkan pembentukan endosperm dan embrio yang menjadi komponen dari benih. Di dalam endosperm terkandung banyak karbohidrat dan lemak sebebagai komponen cadangan makanan benih. Semakin besar bagian endosperm benih maka komponen cadangan makanan seperti karbohidrat menjadi semakin banyak. Pertumbuhan embrio dalam perkecambahan bergantung pada ketersediaan cadangan makanan di dalam endosperm. Selain itu fosfor yang terserap tanaman dari dalam tanah dapat membantu dalam proses metabolisme untuk menghasilkan energi dalam membantu fotosintesis dan respirasi serta sebagai bahan penyusun energi dalam proses fosfolipid. Dengan semakin banyak volume endosperm yang terisi maksimal dalam benih melalui pemberian giberelin diduga meningkatkan kandungan cadangan makanan salah satunya kabohidrat. Di dalam endosperm terkandung banyak karbohidrat dan lemak sebagai komponen cadangan makanan benih. Menurut Aswanti (2001) pada saat perkecambahan, pertumbuhan embrio membutuhkan penyediaan makanan dalam bentuk karbohidrat, protein dan lemak di dalam endosperm. Menurut Vance et al (2003) fosfor membantu dalam proses respirasi, menghasilkan energi, fotosintesis, biosintesis asam nukleat dan sebagai bahan penyusun fosfolipid tanaman.

Berdasarkan hasil uji lanjut dari interaksi aplikasi Fosfor dan $\mathrm{GA}_{3}$ terhadap kandungan karbohidrat biji dapat dilihat pada Tabel 4 dibawah ini.

Tabel 4. Interaksi Aplikasi Fosfor dan $\mathrm{GA}_{3}$ terhadap Karbohidrat Biji

Table 4. Interaction of Phosphorus and GA3 Apliation to seeds Carbohidrate

\begin{tabular}{|c|c|c|c|c|c|c|c|c|}
\hline \multirow[b]{2}{*}{$\begin{array}{c}\text { Dosis Fosfor } \\
\text { Phosphorus dose }\end{array}$} & \multicolumn{8}{|c|}{$\begin{array}{c}\text { Konsentrasi } \mathrm{GA}_{3} \\
\text { Concentration } \mathrm{GA}_{3}\end{array}$} \\
\hline & $\begin{array}{l}\text { Tanpa } \\
(0) \\
\text { Whitho } \\
\text { applice }\end{array}$ & $\begin{array}{l}\text { mberian } \\
\text { on }(0)\end{array}$ & $\begin{array}{l}50 \mathrm{mg} / \\
50 \mathrm{mg} / \mathrm{l}\end{array}$ & & $\begin{array}{l}100 \mathrm{~m} \\
100 \mathrm{~m}\end{array}$ & & $\begin{array}{l}150 \mathrm{~m} \\
150 \mathrm{~m}\end{array}$ & \\
\hline $\begin{array}{l}75 \mathrm{~kg} / \mathrm{ha} \mathrm{SP}-36 \\
75 \mathrm{~kg} / \mathrm{ha} S P-36\end{array}$ & 41,97 & $\mathrm{a}$ & 42,02 & $\mathrm{a}$ & 41,87 & $\mathrm{c}$ & 41,88 & $\mathrm{~b}$ \\
\hline $\begin{array}{l}100 \mathrm{~kg} / \mathrm{ha} \mathrm{SP-36} \\
100 \mathrm{~kg} / \mathrm{ha} \mathrm{SP-36}\end{array}$ & 41,63 & $\mathrm{~cd}$ & 41,56 & de & 41,52 & $\mathrm{e}$ & 41,55 & $\mathrm{e}$ \\
\hline $\begin{array}{l}125 \mathrm{~kg} / \mathrm{ha} \mathrm{SP}-36 \\
125 \mathrm{~kg} / \mathrm{ha} \mathrm{SP-36}\end{array}$ & 41,35 & $\mathrm{f}$ & 41,24 & $\mathrm{~g}$ & 41,26 & $\mathrm{~g}$ & 41,31 & $\mathrm{fg}$ \\
\hline $\begin{array}{l}150 \mathrm{~kg} / \mathrm{ha} \mathrm{SP}-36 \\
150 \mathrm{~kg} / \mathrm{ha} \mathrm{SP-36}\end{array}$ & 41,04 & $\mathrm{~h}$ & 41,05 & $\mathrm{~h}$ & 40,99 & $\mathrm{~h}$ & 40,89 & i \\
\hline
\end{tabular}

Pada Tabel 4. terlihat interaksi perlakuan aplikasi fosfor $75 \mathrm{~kg} / \mathrm{ha} \mathrm{SP}-36$ dan $\mathrm{GA}_{3} 50 \mathrm{mg} / \mathrm{l}$ meningkatkan kandungan karbohidrat benih 42,02\%. Menurut Faizin et al. (2015) unsur fosfor sangat dibutuhkan dalam pembentukan karbohidrat yang digunakan dalam pembentukan organ-organ sel tanaman. Menurut Munawar (2011) fosfat berfungsi sebagai penyimpan dan transfer energi dalam tanaman. Fosfor juga sebagai bagian penting dalam fotosintesis dan metabolisme karbohidrat, pembentukan intisel, pembelahan dan perbanyakan sel. 
Bentuk karbohidrat di dalam tanaman berupa pati atau amilum. Di dalam endosperm terdapat kandungan pati yang diurai secara enzimatik menjadi gula dalam bentuk amilase yang kemudian ditranslokasikan ke embrio sebagai sumber energi dalam perkecambahan. Menurut Hartawan \& Nengsih (2012), indikator kualitas benih berupa vigor ditandai dengan kecepatan daya tumbuh benih yang didukung oleh cadangan makanan dalam bentuk karbohidrat, lemak dan protein dalam benih. Proses perkecambahan benih diawali dengan hidrolisa karbohidrat oleh $\alpha$ dan $\beta$-amylase yang diperantarai oleh giberelin yang diubah menjadi gula maltosa dan glukosa. Beberapa gula glukosa diubah menjadi sukrosa dibantu oleh enzim inertase. Metabolisme glukosa melalui proses glikolisis membentuk ATP dan asam piruvat dan dilanjutkan oleh proses oksidasi dalam siklus krebs yang digunakan sebagai energi utama dalam proses perkecambahan.

Berdasarkan hasil penelitian, aplikasi fosfor dan $\mathrm{GA}_{3}$ dapat meningkatkan daya kecambah benih. Hasil uji lanjut menunjukkan bahwa interaksi perlakuan aplikasi fosfor $75 \mathrm{~kg} /$ ha SP-36 dan $\mathrm{GA}_{3} 50$ $\mathrm{mg} / \mathrm{l}$ meningkatkan daya berkecambah benih menjadi 90\%. Hasil uji lanjut selengkapnya dapat dilihat pada Tabel 5.

Tabel 5. Interaksi Aplikasi Fosfor dan $\mathrm{GA}_{3}$ terhadap Daya Berkecambah Benih

Table 5. Interacrion Phosphorus and GA3 Aplication to Seeds Germination

\begin{tabular}{|c|c|c|c|c|c|c|c|c|}
\hline \multirow[b]{2}{*}{$\begin{array}{c}\text { Dosis Fosfor } \\
\text { Phosphorus Dose }\end{array}$} & \multicolumn{8}{|c|}{$\begin{array}{c}\text { Konsentrasi } \mathrm{GA}_{3} \\
\text { Concentration } \mathrm{GA}_{3} \\
\end{array}$} \\
\hline & \multicolumn{2}{|c|}{$\begin{array}{l}\text { Tanpa pemberian } \\
(0) \\
\text { Whithout } \\
\text { Application (0) }\end{array}$} & \multicolumn{2}{|c|}{$\begin{array}{l}50 \mathrm{mg} / \mathrm{l} \\
50 \mathrm{mg} / \mathrm{l}\end{array}$} & \multicolumn{2}{|c|}{$\begin{array}{l}100 \mathrm{mg} / 1 \\
100 \mathrm{mg} / \mathrm{l}\end{array}$} & \multicolumn{2}{|c|}{$\begin{array}{l}150 \mathrm{mg} / 1 \\
150 \mathrm{mg} / \mathrm{l}\end{array}$} \\
\hline $\begin{array}{l}75 \mathrm{~kg} / \mathrm{h} a \mathrm{SP}-36 \\
75 \mathrm{~kg} / \mathrm{ha} \mathrm{SP-36}\end{array}$ & 65,00 & 1 & 90,00 & $\mathrm{a}$ & 72,00 & $\mathrm{k}$ & 77,76 & $\mathrm{~g}$ \\
\hline $\begin{array}{l}100 \mathrm{~kg} / \mathrm{ha} \mathrm{SP}-36 \\
100 \mathrm{~kg} / \mathrm{ha} \mathrm{SP-36}\end{array}$ & 44,67 & $\mathrm{n}$ & 77,00 & $\mathrm{~h}$ & 80,00 & $\mathrm{e}$ & 88,00 & $\mathrm{~b}$ \\
\hline $\begin{array}{l}125 \mathrm{~kg} / \mathrm{ha} \mathrm{SP}-36 \\
125 \mathrm{~kg} / \mathrm{ha} \mathrm{SP-36}\end{array}$ & 79,00 & $\mathrm{f}$ & 72,00 & $\mathrm{k}$ & 60,00 & $\mathrm{~m}$ & 85,00 & $\mathrm{c}$ \\
\hline $\begin{array}{l}150 \mathrm{~kg} / \mathrm{ha} \mathrm{SP}-36 \\
150 \mathrm{~kg} / \mathrm{ha} \mathrm{SP-36}\end{array}$ & 74,00 & $\mathrm{j}$ & 74,00 & $\mathrm{j}$ & 75,00 & $\mathrm{i}$ & 81,00 & $\mathrm{~d}$ \\
\hline
\end{tabular}

Keterangan: Angka pada kolom yang diikuti oleh huruf yang berdeda pada masing-masing variabel menunjukkan berbeda sangat nyata berdasarkan uji DMRT taraf 5\%.

Information: Nomina in the same column that followed by the same alphabet in each variable was not significant based on the DMRT test at a $5 \%$ level.

Aplikasi $\mathrm{GA}_{3}$ dapat meningkatkan keberhasilan dalam pembentukan buah dan pengisian biji secara maksimal sehingga dapat meningkatkan daya tumbuh benih. Menurut Shahid et al. (2013), pemberian zat pengatur tumbuh $\mathrm{GA}_{3}$ dapat meningkatkan sistem metabolisme dan menghasilkan akumulasi fotosintat yang akhirnya menghasilkan benih dengan presentase daya tumbuh yang lebih baik.

Peningkatan daya tumbuh benih juga dipengaruhi oleh adanya aplikasi fosfor pada tanaman. Fosfor yang terserap tanaman diperlukan untuk menyusun fitin di dalam benih yang dimanfaatkan sebagai energi untuk perkecambahan benih. Di dalam benih bentuk sederhana senyawa fitin adalah asam fitat. Menurut Suprapto (1985) fitin dalam benih digunakan sebagai cadangan energi dalam berkecambah dan meningkatkan mutu benih dengan ditandai persentase daya berkecambah tinggi juga mempengaruhi keserempakan tumbuh kecambah tinggi. Selanjutnya Marschner, 
(2012)menjelaskan bahwa pada awal pembentukan biji kandungan fitat meningkat seiring dengan sintesis pati dan terhenti setelah pati terbentuk. Fitat berkaitan dalam regulasi pati saat proses pengisian biji, selain itu fitat juga digunakan dalam perkecambahan benih melalui sumber $\mathrm{P}$ sebagai sintesis membran lipid asam nukleat. Berdasarkan hasil penelitian Lesilolo (2012), aplikasi pupuk fosfor dengan beberapa taraf pada tanaman jagung dapat meningkatkan daya berkecambah dan kecepatan tumbuh benih.

\section{KESIMPULAN}

Kombinasi perlakuan aplikasi fosfor $75 \mathrm{~kg} / \mathrm{ha}$ SP-36 dan konsentrasi $\mathrm{GA}_{3}$ $50 \mathrm{mg} / 1$ meningkatkan daya kecambah benih sebesar 90\% dan kandungan karbohidrat benih okra sebesar 42\%. Aplikasi $\mathrm{GA}_{3}$ konsentrasi $50 \mathrm{mg} / \mathrm{l}$ dapat meningkatkan berat biji pada variable berat biji per polong sebesar 3,77 gram, berat bji per tanaman sebesar 49,2 gram dan produksi biji sebesar 1,98 ton/ha.

\section{DAFTAR PUSTAKA}

Abd El-Kader, A., Shaaban, S., \& Abd ElFattah, M. (2010). Effect of Irrigation Levels and Organic Compost on Okra Plants (Abelmoschus esculentus 1.) Grown in Sandy Calcareous Soil. Agriculture and Biology Journal of North America, 1(3), 225-231. https://doi.org/10.5251/abjna.2010.1. 3.225 .231

Arifin, Z., Yudono, P., \& Toekidjo. (2012). Pengaruh Konsentrasi GA3 Terhadap Pembungaan dan Kualitas Benih Cabai Merah Keriting (Capsicum annuum L.). Fakultas Pertanian Gadjah Mada, Yogyakarta, 1(4). https://doi.org/10.22146/veg.1604 https://jurnal.ugm.ac.id/jbp/article/vi ew/1604
Aswanti, H. (2001). Pengaruh Suhu dan Lama Perendaman terhadap Perkecambahan dan Pertumbuhan Bibit Kopi Robusta (Coffea canophoora Pierre) [Skripsi]. Universitas Riau.

Barutu, D. P. S. (2016). Penentuan Dosis Optimum Pemupukan Nitrogen dan Kalium untuk Produksi Benih Kenikir [Tesis, Institut Pertanian Bogor].

Faizin, N., Mardhiansyah, M., \& Yoza, D. (2015). Respon Pemberian Beberapa Dosis Pupuk Fosfor Terhadap Pertumbuhan Semai Akasia (Acacia mangium willd.) dan Ketersediaan Fosfor di Tanah. JOM Faperta, 2(2).

Hadisuwito, S. (2012). Membuat Pupuk 尌 Organik Cair. AgroMedia.

Hartawan, R., \& Nengsih, Y. (2012). Kadar EQ Air dan Karbohidrat Benih Berperan Peting dalam Pertambahan Kualitas Benih Karet. Agrovigor, 5(2), 103112.

Ichsan, M. C., Santoso, I., \& Oktarina. EQ (2016). Uji Efektivitas Waktu Aplikasi Bahan Organik dan Dosis Pupuk Sp-36 Dalam Meningkatkan Produksi Okra (Abelmoschus esculentus). Agritrop Jurnal IlmuIlmu Pertanian, 134-150.

Indreswari, A. (2015). Mitratani Perluas 暿Q Pasar Ekspor Sayuran.

Khandaker, M. M., Azam, H. M., Rosnah, 尌 J., Tahir, D., \& Nashriyah, M. (2018). The Effects of Application of Exogenous IAA and GA3 on The Physiological Activities and Quality of Abelmoschus esculentus (Okra) var. Singa 979. Pertanika J. Trop. Agric. Sci, 4(1), 209-224. 
Kirana, R., Gaswanto, R., \& Hidayat, I. M. (2015). Budidaya dan Produksi Benih Okra. Pusat Penelitian Dan Pengembangan Hortikultura.

Lesilolo, M. K. (2018). Studi Pemupukan Fosfat Terhadap Viabilitas dan Vigor Benih Jagung (Zea mays L.) Varietas Hulaliu. Agrologia, 1(2), 119-125. https://doi.org/10.30598/a.v1i2.287

Marschner, H. (2012). Marschner's Mineral Nutrition of Higher Plants. Elsevier. https://doi.org/10.1016/ C2009-0-63043-9

Muharram, M., Setiawan, E., \& Pawana, G. EQ (2015). Penggunaan Hormon Giberelin dalam Upaya Peningkatan Kualitas Buah Duwet. Seminar Nasional: Optimalisasi Potensi Hayati Lahan Kering, 220-227.

Muhyidin, H., Islami, T., \& Maghfoer, M. D. (2018). Pengaruh Konsentrasi dan Waktu Pemberian Giberelin pada Pertumbuhan dan Hasil Tanaman Tomat (Lycopersicon esculentum Mill.). Jurnal Produksi Tanaman, 6(6), 1147-1154.

Munawar, A. (2011). Kesuburan Tanah 琶 dan Nutrisi Tanaman. Penerbit IPB Press.

Shahid, M. R., Amjad, M., Ziaf, K., 琶 Jahangir, M. M., Ahmad, S., Iqbal, Q., \& Nawaz, A. (2013). Growth, Yield and Seed Production of Okra as Influenced by Different Growth Regulators. Pakistan Journal of Agricultural Sciences, 50(3), 387392.

Suprapto, H. S. (1985). Bertanam kedelai. 尌 Penebar Swadaya.
Vance, C. P., Uhde-Stone, C., \& Allan, D. EQ L. (2003). Phosphorus Acquisition and Use: Critical Adaptations by Plants for Securing a Nonrenewable Resource. New Phytologist, 157(3), 423-447. https://doi.org/10.1046/ j.1469-8137.2003.00695.x

Wijayanto, T., Yani, W. O. R., \& Arsana, EQ M. W. (2012). Respon Hasil dan Jumlah Biji Buah Semangka (Citrullus vulgaris) dengan Aplikasi Hormon Giberelin (GA3). Jurnal Agroteknos, 2(1), 2087-7706.

Winata, N. A. S. H., Lukiwati, D. R., \& , EQ dan Purbajanti, E. D. 2. (2014). Kualitas Jerami Sorgum Manis Varietas Numbu dengan Pemberian Pupuk Sumber Fosfat yang Berbeda. Agrovigor, 7(1), 63-69. https:// doi.org/10.36626/jppp.v11i21.132

Wiraatmaja, I. W. (2017). Zat Pengatur 㖵 Tumbuh Giberelin dan Sitokinin.

Zulkarnain. (2010). Dasar-Dasar 尌 Hortikultura. Bumi Aksara. 